\title{
The Current State of the Herb-Shrub Association with the Participation of the Red Book Endemic Species Juno Orchioides in the Tashkent Region (Uzbekistan)
}

\author{
Nargiza K. Rakhimova*, Guljan M. Duschanova, Eldor E. Temirov, \\ Akida T. Abdullaeva, Sobitjon S. Nosirov, Ismat N. Samadov \\ Laboratory Anatomy and Cytoembryology of the Tashkent Botanical Garden Named after Academician F.N. Rusanov, Institute of \\ Botany of the Academy of Sciences, Tashkent, Uzbekistan
}

\begin{abstract}
The article provides a review of studies of the vegetation cover of the Western Tien Shan of the NorthEastern slope of the Kurama ridge of the Parkent district (the left bank of Parkentsai) with the participation of the rare endemic species Juno orchioides. The article presents the main results of work in the field of geobotany and botanical geography carried out in the Tashkent region. A list of plants of 4 communities of the herb-shrub association with the participation of the species Juno orchioides is given. The association contains more than 90 species of plants. Of these, trees -10 , shrubs -9 , perennials -71 , annuals 8. Anthropogenic factors and grazing are the reason for the decrease in this species of Juno orchioides, and in the future, measures for reintroduction must be applied to preserve and restore this species.
\end{abstract}

Keywords:- Vegetation, Herb-Shrub Association, Juno Orchioides, Tashkent Region.

\section{INTRODUCTION}

It is known that co-growing plants form a plant community, or phytocenosis. A plant community is a collection of plants growing on one part of the earth's surface, adapted to live together and affect each other and the environment.

Plant association is a common generic concept, differing not only in volume, but also in its essence. Community is a local, concrete concept, while association is an abstract concept, the result of generalization [1].

According to U. Allanazarova, A.Ya. Butkova and M.M. Nabieva [2], in Uzbekistan in 1923 variegated rocks (as part of Juno narynensis) of the Southern Pamir-Alai were originally studied by M.G. Popov. U. Allanazarova, A.Ya. Butkov, G.Kh. Khamidov in 1984 as part of a plane- tree formation, the species Juno warleyensis is found with an abundance of $\mathrm{Sp}^{2}$ [3]. R.S. Wernick, R.D. Melnikova, Sh.K. Kamalov [4] studied juniper formation (Juniperus semiglobosa) with the participation of Juno tadshikorum. As part of this formation, Juno tadshikorum is found with an abundance of $\mathrm{Sp}^{2}$. In the Juniperus turkestanica formation, the species Juno parvula is found with an abundance of sol.

Plant communities with the participation of the Red Book endemic species Juno orchioides, which grows in Uzbekistan, have not been previously studied. This determines the relevance and novelty of our research.

The purpose of the study is to study the current state of the herb-shrub association with the participation of the Red Book endemic species Juno orchioides in the Tashkent region.

\section{MATERIALS AND METHODS}

We conducted a study on the distribution of the Red Book endemic species Juno orchioides Tratt. on the herbshrub community in the Tashkent region (Western Tien Shan, on the northeastern slope of the Kurama ridge of the Parkent district, on the left bank of Parkentsai) 2018-2019.

Juno orchioides - the investigated samples were taken: $41^{\circ} 18^{\prime} 48.857^{\prime \prime} \mathrm{N}$ lat. $69^{\circ} 50^{\prime} 38.393 "$ in. d. 14. IV. 2014 (Fig. 1). It is listed in the Red Book of the Republic of Uzbekistan [5], it is a rare endemic of the Western Tien Shan with status 3. Perennial tuberous plant. The roots are cord-shaped, slightly thickened. Bulb $2 \mathrm{~cm}$ thick. Stalk 10$30 \mathrm{~cm}$ tall, with leaves spaced; internodes are noticeable, at least at the end of flowering. The leaves are light green, sickle-shaped, bordered along the edge, rough, gradually narrowed to the apex; lower $2-5 \mathrm{~cm}$ wide. 
ISSN No:-2456-2165
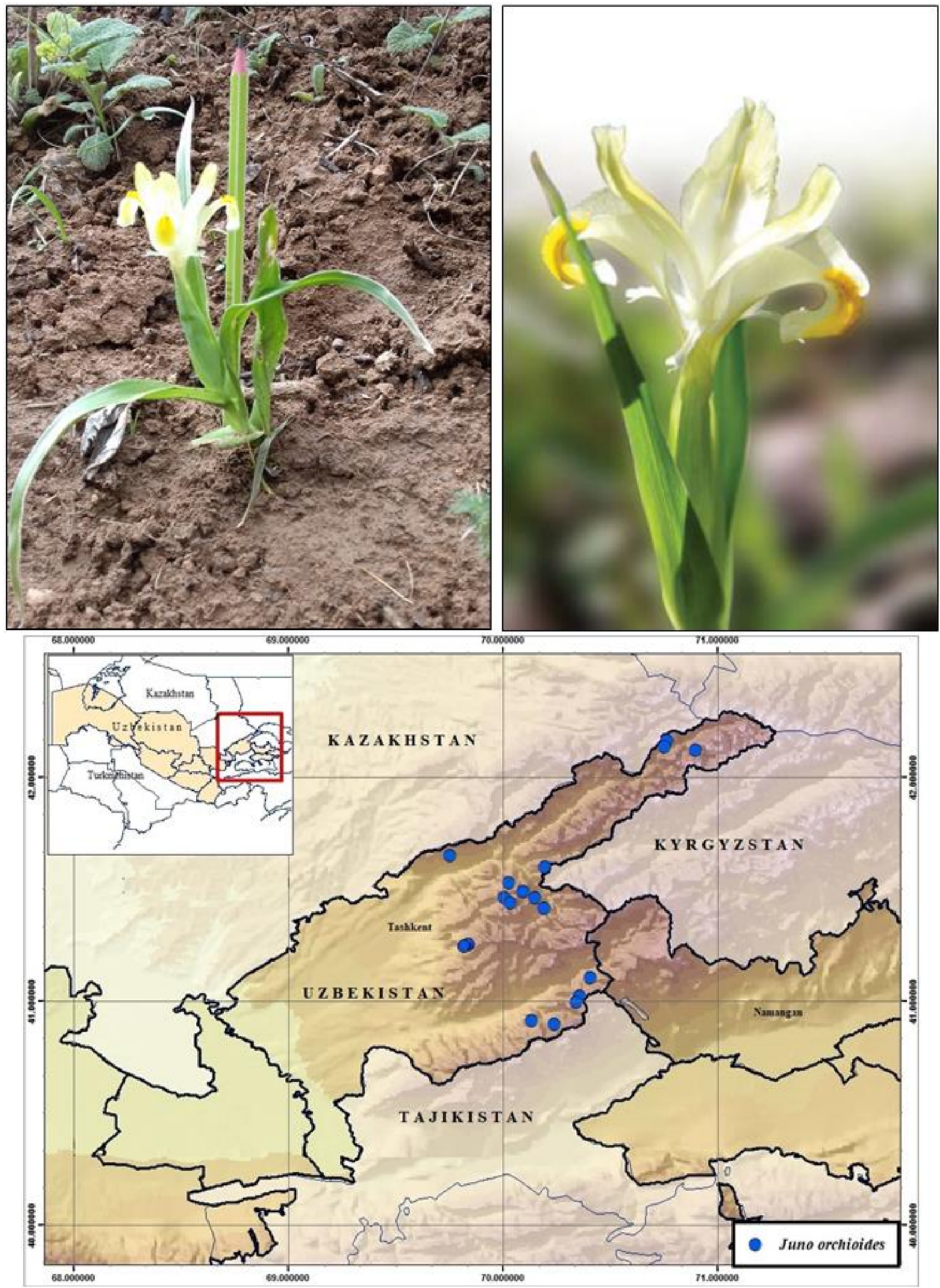

Fig 1:- General view and distribution map of Juno orchioides in Tashkent region 
Ecology: clay and rocky slopes in the foothills and middle and lower zones of the mountains. Range: Central Asia (Western Tien Shan). Uzbekistan When describing herb-shrub communities in the Tashkent region, they used the "Methodological guidelines for the geobotanical examination of the natural forage lands of Uzbekistan" [6].

\section{RESULTS AND DISCUSSION}

In 2018-2019 a study was conducted on the occurrence of the Red Book endemic species Juno orchioides Tratt. on the forbs and shrubs community in the Tashkent region. Four communities $30 \times 30 \mathrm{~m}$ in size were studied. The height of the studied territory reaches from 1256 to $1329 \mathrm{~m}$ above sea level. These communities differ in soil composition: the soil of the first community is stonygravel, gray earth; the soil of the second is black earth, less often stony; the soil of the third is black earth, less often stony; the fourth - black earth, less often stony.

As a result of the studies, the variability of the composition of plant species of the 4 studied communities was noted. The total degree of vegetation coverage of the soil is $70-80 \%$, the aspect is green. Of these, trees and shrubs account for $40-50 \%$, the rest are annual and perennial plants, and ephemera accounted for $30 \%$ (table $1)$.

The main plant species as edificators are: Crataegus turkestanica, Malus sieversii, Prunus divaricata, Crataegus pontica, Acer semenovii; and as a co-identifier are: Lonicera altmannii, Lonicera nummulariifolia, Rosa kokanica, Rosa fedtschenkoana, Ceracus erythrocarpa, Spiraea hypericifolia, Cotoneaster multiflora; the dominant communities are Glysyrrhiza glabra, Hypericum scabrum, Poa bulbosa, Ziziphora pedicellata, Cousinia radians, Bromus danthoniae.

Acroptilon repens, Achillea biebersteini, Eremurus regelii, Haplophyllum perforatum, Plantago lanceolata, Prangos pabularia, Phlomoides speciosa, Verbascum songaricum, Ceratocephalus testiculatatus met as adventitious species.

\begin{tabular}{|c|c|c|c|c|}
\hline Species & 1 & 2 & 3 & 4 \\
\hline \multicolumn{5}{|c|}{ Trees } \\
\hline Acer turkestanicum Pax. & $\mathrm{Sp}^{1}$ & - & - & - \\
\hline Acer semenovii Regel et Herd. & Sol & $\mathrm{Sp}^{2}$ & - & - \\
\hline Crataegus turkestanica A. Pojark. & $\mathrm{Sp}^{3}$ & $\mathrm{Sp}^{2}$ & $\mathrm{Sp}^{2}$ & - \\
\hline Crataegus pontica $\mathrm{C}$. Koch. & Sol & $\mathrm{sp}^{2}$ & Sol & - \\
\hline Elaeagnusorientalis L. & & - & - & $\mathrm{Sp}^{1}$ \\
\hline Juniperus turkestanica Kom. & Sol & - & - & - \\
\hline Malus sieversii (Ledeb.) M. Roem. & $\mathrm{Sp}^{1}$ & Sol & Sol & - \\
\hline Padus mahaleb (L.)Vass. & - & $\mathrm{Sp}^{1}$ & - & - \\
\hline Prunus divaricate Ledeb. & $\mathrm{Sp}^{1}$ & $\mathrm{Sp}^{1}$ & Sol & - \\
\hline Pistacia vera $\mathrm{L}$. & - & - & - & Sol \\
\hline \multicolumn{5}{|c|}{ Shrubs } \\
\hline Berberis oblonga Schneid. & Sol & $\mathrm{Sp}^{1}$ & $\mathrm{Sp}^{1}$ & - \\
\hline Ceracus erythrocarpa Nevski & $\mathrm{Sp}^{3}$ & $\mathrm{Sp}^{1}$ & - & $\mathrm{Sp}^{1}$ \\
\hline Cotoneaster multiflora Bunge. & Sol & $\mathrm{Sp}^{1}$ & $\mathrm{Sp}^{1}$ & $\mathrm{Sp}^{1}$ \\
\hline Ephedra equisetina Bunge & - & - & - & Sol \\
\hline Lonicera altmannii Regel et Schmalh. & $\mathrm{sp}^{1}$ & $\mathrm{Sp}^{2}$ & $\mathrm{Sp}^{2}$ & $\mathrm{Sp}^{1}$ \\
\hline Lonicera nummulariifolia Jaub. et Spach & $\mathrm{Sp}^{1}$ & $\mathrm{Sp}^{1}$ & $\mathrm{Sp}^{2}$ & $\mathrm{Sp}^{1}$ \\
\hline Rosa kokanica (Regel) Juz. & $\mathrm{Sp}^{2}$ & $\mathrm{Sp}^{2}$ & $\mathrm{Sp}^{2}$ & $\mathrm{Sp}^{1}$ \\
\hline Rosa fedtschenkoana Regel & $\mathrm{Sp}^{2}$ & $\mathrm{Sp}^{1}$ & $\mathrm{Sp}^{2}$ & $\mathrm{Sp}^{1}$ \\
\hline Spiraea hypericifolia $\mathrm{L}$. & $\mathrm{Sp}^{1}$ & $\mathrm{Sp}^{1}$ & $\mathrm{Sp}^{1}$ & $\mathrm{Sp}^{1}$ \\
\hline \multicolumn{5}{|c|}{ Perennial herbaceous plants } \\
\hline Aegilops triuncialis $\mathrm{L}$. & - & - & - & $\mathrm{Sp}^{2}$ \\
\hline Allium borsczewskii Lipsky & Sol & Sol & Sol & $\mathrm{Sp}^{1}$ \\
\hline Arctium lappa $\mathrm{L}$. & $\mathrm{Sp}^{1}$ & - & - & - \\
\hline Arctium lejospermumJuz. et Serg. & - & $\mathrm{Sp}^{1}$ & - & - \\
\hline Artemisia absinthium $\mathrm{L}$. & Sol & - & Sol & $\mathrm{Sp}^{2}$ \\
\hline Artemisia dracunculus L. & - & $\mathrm{Sp}^{1}$ & - & - \\
\hline Arum korolkovii Regel & $\mathrm{Sp}^{1}$ & - & $\mathrm{Sp}^{1}$ & $\mathrm{Sp}^{2}$ \\
\hline Astragalus ophiocarpys Bent. & Sol & Sol & $\mathrm{Sp}^{1}$ & - \\
\hline
\end{tabular}


ISSN No:-2456-2165

\begin{tabular}{|c|c|c|c|c|}
\hline Astragalus eximius Bunge & - & - & Sol & $\mathrm{Sp}^{1}$ \\
\hline Astragalus alopecias Pall. & - & - & Sol & - \\
\hline Aster canescens (Ness.) Fisjun & - & - & - & $\mathrm{Sp}^{1}$ \\
\hline Acroptilon repens (L.) D C. & $\mathrm{Sp}^{2}$ & $\mathrm{sp}^{1}$ & $\mathrm{Sp}^{1}$ & $\mathrm{Sp}^{1}$ \\
\hline Acanthophyllum albidum Schischk. & - & $\mathrm{Sp}^{1}$ & - & - \\
\hline Achillea biebersteinii Afan. & $\mathrm{Sp}^{1}$ & $\mathrm{sp}^{2}$ & $\mathrm{Sp}^{1}$ & $\mathrm{Sp}^{1}$ \\
\hline Achillea millefolium $\mathrm{L}$. & $\mathrm{Sp}^{1}$ & $\mathrm{Sp}^{1}$ & $\mathrm{Sp}^{2}$ & - \\
\hline Achillea filipendulina Lam. & $\mathrm{Sp}^{1}$ & $\mathrm{Sp}^{1}$ & $\mathrm{Sp}^{2}$ & $\mathrm{Sp}^{2}$ \\
\hline Bromus danthoniae Trin. & $\mathrm{Sp}^{1}$ & $\mathrm{Sp}^{2}$ & - & $\mathrm{Sp}^{1}$ \\
\hline Bromus turkestanicus Drobow & $\mathrm{Sp}^{1}$ & - & - & - \\
\hline Bromus inermis Leyss. & - & $\mathrm{Sp}^{1}$ & - & $\mathrm{Sp}^{1}$ \\
\hline Clematis orientalis L. & Sol & - & - & - \\
\hline Cousinia vicarial M. Kult. & $\mathrm{Sp}^{1}$ & - & - & $\mathrm{Sp}^{1}$ \\
\hline Cousinia radians Bunge & - & Sol & $\mathrm{Sp}^{2}$ & $\mathrm{Sp}^{2}$ \\
\hline Cynodondactylon (L.) Pers. & - & $\mathrm{Sp}^{1}$ & - & - \\
\hline Carex pachystylis J. Gay. & $\mathrm{Sp}^{2}$ & - & $\mathrm{Sp}^{1}$ & - \\
\hline Dictamnus angustifolius G. Donfel. ex Sweet & - & - & - & $\mathrm{Sp}^{2}$ \\
\hline Eminium lehmannii (Bunge) O. Kuntze & $\mathrm{Sp}^{1}$ & - & - & $\mathrm{Sp}^{1}$ \\
\hline Euphorbia sp. & - & - & - & $\mathrm{Sp}^{1}$ \\
\hline Eremurus regelii Vved. & - & $\mathrm{Sp}^{1}$ & $\mathrm{Sp}^{2}$ & - \\
\hline Elytrigia trichophora (Link) Nevski & - & - & - & $\mathrm{Sp}^{2}$ \\
\hline Echinops karatavicus Regel \& Schmalh. & - & - & - & $\mathrm{Sp}^{2}$ \\
\hline Ferula tenuisecta Korovin & Sol & Sol & $\mathrm{Sp}^{1}$ & $\mathrm{Sp}^{1}$ \\
\hline Galatella coriacea Novopokr. & - & - & - & $\mathrm{Sp}^{1}$ \\
\hline Galium pamiroalaicum Pobed. & - & - & Sol & $\mathrm{Sp}^{1}$ \\
\hline Glycyrrhiza glabra L. & Sol & $\mathrm{Sp}^{1}$ & $\mathrm{Sp}^{1}$ & $\mathrm{Sp}^{2}$ \\
\hline Gentiana olivieri Griseb. & - & - & - & $\mathrm{Sp}^{2}$ \\
\hline Haplophyllum perforatum Kar. et Kir. & - & $\mathrm{Sp}^{1}$ & - & $\mathrm{Sp}^{1}$ \\
\hline Helichrysum maracandicum Popov ex Kirp. & - & - & - & $\mathrm{Sp}^{1}$ \\
\hline Hypericum scabrumL. & $\mathrm{Sp}^{1}$ & $\mathrm{Sp}^{1}$ & $\mathrm{Sp}^{1}$ & $\mathrm{Sp}^{1}$ \\
\hline Hypericum perforatum $\mathrm{L}$. & $\mathrm{Sp}^{1}$ & $\mathrm{Sp}^{1}$ & $\mathrm{Sp}^{1}$ & $\mathrm{Sp}^{1}$ \\
\hline Hordeum bulbosum $\mathrm{L}$. & $\mathrm{Sp}^{1}$ & $\mathrm{Sp}^{2}$ & $\mathrm{Sp}^{1}$ & $\mathrm{Sp}^{1}$ \\
\hline Holosteum polygamum C. Koch. & - & $\mathrm{Sp}^{1}$ & $\mathrm{Sp}^{1}$ & - \\
\hline Inula helenium $\mathrm{L}$. & - & $\mathrm{Sp}^{1}$ & - & $\mathrm{Sp}^{2}$ \\
\hline Juno orchioides Tratt. & Sol & - & - & $\mathrm{Sp}^{1}$ \\
\hline Lamium album L. & - & - & - & $\mathrm{Sp}^{1}$ \\
\hline Ligularia thomsonii (Clarke) Pojark. & - & - & $\mathrm{Sp}^{1}$ & $\mathrm{Sp}^{2}$ \\
\hline Mentha asiatica Boriss. & - & - & $\mathrm{Sp}^{2}$ & - \\
\hline Meniocus linifolius (Steph.) DC. & $\mathrm{Sp}^{1}$ & - & Sol & - \\
\hline Medicago sativa $\mathrm{L}$. & $\mathrm{Sp}^{1}$ & - & $\mathrm{Sp}^{1}$ & - \\
\hline Onosma dichroanthum Boiss. & - & Sol & - & $\mathrm{Sp}^{2}$ \\
\hline Origanum tytthanthum Gontsch. & $\mathrm{Sp}^{1}$ & $\mathrm{Sp}^{1}$ & $\mathrm{Sp}^{1}$ & $\mathrm{Sp}^{1}$ \\
\hline Orobanche uralensis G.Beck & Sol & $\mathrm{Sp}^{1}$ & $\mathrm{Sp}^{1}$ & $\mathrm{Sp}^{1}$ \\
\hline Plantago lanceolata $\mathrm{L}$. & $\mathrm{Sp}^{1}$ & $\mathrm{Sp}^{1}$ & $\mathrm{Sp}^{1}$ & $\mathrm{Sp}^{1}$ \\
\hline Polygonum polycnemoides Jaub. et Spach. & $\mathrm{Sp}^{2}$ & - & Sol & - \\
\hline Poa bulbosa L. & $\mathrm{Sp}^{1}$ & $\mathrm{Sp}^{2}$ & $\mathrm{Sp}^{1}$ & $\mathrm{Sp}^{1}$ \\
\hline Phleum paniculatum Huds. & $\mathrm{Sp}^{1}$ & - & - & - \\
\hline Phlomoides speciose (Rupr.) Adylov, Kamelin et Makhm. & $\mathrm{Sp}^{1}$ & Sol & $\mathrm{Sp}^{1}$ & $\mathrm{Sp}^{1}$ \\
\hline Prangos pabularia Lindl. & $\mathrm{Sp}^{1}$ & $\mathrm{Sp}^{1}$ & $\mathrm{Sp}^{2}$ & $\mathrm{Sp}^{2}$ \\
\hline Ranunculus leptorrhynchus Aitch. et Hemsl. & - & $\mathrm{Sp}^{1}$ & $\mathrm{Sp}^{1}$ & - \\
\hline Rochelia disperma C. Koch. & $\mathrm{Sp}^{2}$ & - & - & - \\
\hline Ranunculus linera $\mathrm{L}$. & - & - & $\mathrm{Sp}^{1}$ & - \\
\hline
\end{tabular}


ISSN No:-2456-2165

\begin{tabular}{|c|c|c|c|c|}
\hline Salvia sclarea $\mathrm{L}$. & Sol & Sol & $\mathrm{Sp}^{1}$ & $\mathrm{Sp}^{2}$ \\
\hline Taraxacum officinale Web. & - & Sol & Sol & - \\
\hline Trifolium repens $\mathrm{L}$. & $\mathrm{Sp}^{1}$ & - & - & $\mathrm{Sp}^{1}$ \\
\hline Trifolium pratense $\mathrm{L}$. & $\mathrm{Sp}^{1}$ & $\mathrm{Sp}^{1}$ & $\mathrm{Sp}^{2}$ & - \\
\hline Tragopogon turkestanicus S. Nik. & - & - & - & Sol \\
\hline Tragopogon capitatus S. Nik. & - & - & - & $\mathrm{Sp}^{1}$ \\
\hline Tussilago farfara $\mathrm{L}$. & - & - & - & $\mathrm{Sp}^{2}$ \\
\hline Verbascum songaricum Schrenk & $\mathrm{Sp}^{2}$ & $\mathrm{Sp}^{2}$ & $\mathrm{Sp}^{2}$ & $\mathrm{Sp}^{2}$ \\
\hline Vicia gracilior M. Pop. & - & Sol & - & - \\
\hline Vicia tenuifolia Roth. & $\mathrm{Sp}^{1}$ & - & - & Sol \\
\hline Ziziphora pedicellata Pazij.etVved. & $\mathrm{sp}^{2}$ & $\mathrm{Sp}^{2}$ & $\mathrm{Sp}^{2}$ & $\mathrm{Sp}^{1}$ \\
\hline \multicolumn{5}{|c|}{ Annual herbaceous plants } \\
\hline Capsella bursa-pastoris(L.) Medik. & Sol & - & - & - \\
\hline Ceratocephalus testiculatatus Crantz Besser. & $\mathrm{Sp}^{1}$ & $\mathrm{Sp}^{1}$ & $\mathrm{Sp}^{1}$ & $\mathrm{Sp}^{1}$ \\
\hline Erodium cicutarium (L.) L'Her. & - & - & - & $\mathrm{Sp}^{2}$ \\
\hline Koelpinia linearis Pall. & $\mathrm{Sp}^{1}$ & - & - & - \\
\hline Scabiosa micrantha Desf. & - & - & - & $\mathrm{Sp}^{2}$ \\
\hline Tortula desertorum Broth. & - & $\mathrm{Sp}^{1}$ & - & - \\
\hline Tithymalus falcatus $\mathrm{L}$. & $\mathrm{Sp}^{1}$ & - & - & - \\
\hline Trigonella grandiflora Bunge & - & - & Sol & - \\
\hline
\end{tabular}

Table 1:- List of plants of communities of the herb-shrub association with the participation of the species Juno orchioides

The bedding of the grass stand is well defined, 4 tiers stand out. The first tier - 3-6 m high, consists of Crataegus turkestanica, Malus sieversii, Acer semenovii; the second tier - 1.5-2 m high, are Rosa kokanica, Rosa fedtschenkoana, Ceracus erythrocarpa, Spiraea hypericifolia, Cotoneaster multiflora; the third tier - 60$100 \mathrm{~cm}$ high - perennial plants are found, such as: Acroptilon repens, Achillea biebersteini, Hypericum scabrum, Hypericum perforatum, Hordeum bulbosum, Origanum tytthanthum, Poa bulbosa, Ziziphora pedicellata, Cousinia radians, Bromus danthoniae, Glysyrrhiza glabra, Poa bulbosa. The remaining species belong to the fourth tier.

In the study area, there was a unique population of the rare red endemic plant Juno orchioides, the height of which reaches $30-35 \mathrm{~cm}$. This species was noted in the state of fruiting in the amount of 5-6 pieces. 2 years ago, 18-20 copies of Juno orchioides were recorded in the same territory. The reason for the decrease in this population, obviously, is the location near the populations of the tourist zone, which is the main reason for the disappearance of this species.

Below is a list of plants of 4 communities of the herbshrub association with the participation of the species Juno orchioides (table 1). As can be seen from the table, more than 90 plant species are found in the association. Of these, trees -10 , shrubs -9 , perennials -71 , annuals -8 . It is known that the abundance of perennials in the plant community $(78 \%)$ is a characteristic feature for all mountainous areas of Central Asia.

\section{CONCLUSION}

Thus, for the first time, a study was conducted on the distribution of the endemic species Red Book Juno orchioides on the herbaceous-shrub community of the Western Tien Shan of the Northeast slope of the Kurama Range. The occurrence of some species in only one area was noted (Juniperus turkestanica, Elaeagnus orientalis, Pistacia vera, Ephedra equisetina, Vicia gracilior, Rochelia disperma, Ranunculus linera, Elytrigia trichophora, Phleum paniculatum, Phlomoides speciosa, etc.). It should also be noted a decrease in vegetation cover on the upper zones of the mountain. The reason for the decrease in the number of Juno orchioides species in the study area is apparently due to the influence of anthropogenic factors and cattle grazing, and in the future, reintroduction measures must be applied to preserve and restore this species. The diversity of adventitious species in these associations indicates the presence of various forms of anthropogenic pressure in the territory.

\section{ACKNOWLEDGEMENTS}

The current research is done under the project VAFA-F5-008 "Scientific bases for the conservation of the gene pool of rare endemic species of the flora of Uzbekistan ex situ and the biology of their reproduction". 


\section{REFERENCES}

[1]. http://www.bibliotekar.ru/2-7-67-fitocenologiyageobotanika/ 5.htm

[2]. Allanazarova U., Butkov A.Ya., Nabiev M.M. (1976) The vegetation of variegated lowlands Oreogypsophyta. Vegetation cover of Uzbekistan. Tashkent: Fan. 3:227-234.

[3]. Allanazarova U., Butkov A.Ya., Khamidov G.Kh. (1984) Mountain deciduous forests and shrubs of the mesophilic warehouse - Therodendra. Vegetation cover of Uzbekistan. Tashkent: Fan. 4:40-43.

[4]. Vernik R.S., Melnikova R.D., Kamalov Sh.K. (1984) Archevniki - Arceuthodendra. Vegetation cover of Uzbekistan. Tashkent: Fan. 4:136-141; 152-155.

[5]. Rakhimova N. (2019) Genus Iris L. - I. orchioides Carriere. Red Book of the Republic of Uzbekistan. Tashkent: Chinor ENK. 1:78-79.

[6]. Guidelines for the geobotanical survey of natural forage lands in Uzbekistan. 1980. Tashkent: Fan. 170 p. 